\title{
Neuroanatomical Mapping of s100 Immunoreactivity Reviewed
}

\author{
LMG Campos ${ }^{1,2 *}$, L. Pinato ${ }^{2}$, CSG Spilla', AL Decanini' ${ }^{1}$, IZ Vieira ${ }^{1}$, MY Hamasaki' and MI Nogueira ${ }^{1}$
}

${ }^{1}$ Institute of Biomedical Sciences, University of São Paulo, São Paulo, SP, Brazil

${ }^{2}$ Department of Speech-Language and Hearing Therapy, São Paulo State University, Marilia, SP, Brazil

\begin{abstract}
$\mathrm{S} 100 \mathrm{~B}$ is a small calcium-binding protein expressed primarily by astrocytes involved in several pathologies. Several studies have shown S100B protein immunoreactivity (S100B-IR) in brain specific areas, and some of them showed the cells identity under physiological and/or pathological conditions. This review reports the S100BIR distribution in the brain specific areas of different adult mammals and complement with our results in order to provide a complete overview about the S100B-IR distribution and cell identity. This review highlights a heterogeneous distribution of S100B-IR in prosencephalic, diencephalic, brainstem and cerebellum areas. Regarding cellular identity, the co-localization of S100B-IR and GFAP-IR occurred predominantly in periventricular areas, in the hippocampus and the septal area in contrast with cortical regions. In addition, cells S100B-IR but not GFAP-IR were also found in these areas. The analysis throughout the rostro-caudal axis of the brain showed that S100B-IR did not present colocalization with neurons (NeuN-IR). This complete description can be potentially used for researches that aim to consider changes in S100B expression in different pathologies.
\end{abstract}

Keywords: Biomarker; Rats; Calcium-binding protein; Immunohistochemistry; Mapping; Astrocytes

\section{Introduction}

$\mathrm{S} 100 \mathrm{~B}$ is a calcium-binding protein produced and released constitutively mainly by astrocytes, and like other S100 proteins it interacts with several effector proteins exerting intra and extracellular actions.

Many hypotheses have been formulated concerning the biological role(s) of this protein found in soluble form in intracellular membranes, centrosomes, microtubules and type III intermediate filaments $[1,2]$. Although the cellular production of S100B is primarily involved in the modulation of the intracellular milieu, S100B is also secreted in a regulated manner, and it is possible to detect it both in brain tissue or in bodily fluids $[3,4]$.

Most S100B studies have been performed in bodily fluids of humans in pathological conditions or in animal pathological models since increased levels of S100B have been positively correlated with brain pathological conditions [5]. For example, S100B was examined in the CSF (cerebrospinal fluid) and serum of adult patients with acute cerebral infarction, meningitis, multiple sclerosis, dementia, and others neurological pathologies [6-10].

In the central nervous system (CNS), the immunoreactivity (IR) of this protein has been found in astrocytes, oligodendrocytes, Bergman and ependymal cells types. Regarding to the presence of S100B-IR in neurons, results in our lab showed a lack of colocalization of S100B in mature neurons in the rat brain (Figure 1), in contrast to (adult) human brain [11].

Looking for elucidate the role of this protein, several studies in the literature have shown S100B expression in specific areas, and some mapped the identity and distribution of the expressing this protein in the brain under physiological and pathological conditions. In this review we summarize and discuss the main findings on S100B distribution along the brain rostrocaudal axis and its strict cell localization described in the literature and with data of our laboratory.

During normal physiological conditions, S100B acts changing calcium levels to regulate the activity of target proteins which are related to normal cellular function [2], besides a neurotrophic role during brain development [12].
It has been shown that this protein affects neuronal electrical discharge activity by modulating potassium currents at very low concentrations [13].

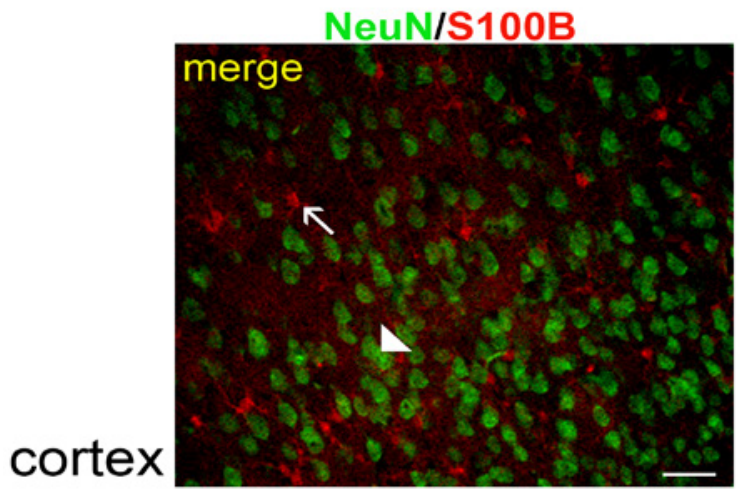

Figure 1: Different shapes of S100B-IR cells in brain coronal sections of adult male rats. The expression of $\mathrm{S} 100 \mathrm{~B}$ along the rostrocaudal axis revealed cells that had different cellular morphology. Bright-field photomicrographs showing the different shapes of S100B-IR cells. (a1) and (a2): S100B-IR Bergman cells that have an irregular shape, (b1): S100B-IR ependymal cell that have a rounded shape, (c1): S100B-IR astrocytes that have an oval shape. (c2): S100B-IR astrocytes that have few cytoplasmic ramifications. (a), (b), and (c): Nissl staining. Scale bars, $100 \mu \mathrm{m}$ in (a1), (a2), (b1), (b2), (c1) and (c2); $20 \mu \mathrm{m}$ in (a), (b) and (c)

*Corresponding author: Leila Maria Guissoni Campos, Department of SpeechLanguage and Hearing Therapy, São Paulo State University, Av. Hygino Muzz Filho, 737 Bairro: Mirante 17.525-000 - Marília, SP, Brazil, Tel: 55-14-3402-1324 E-mail: leilacampos@usp.br

Received October 27, 2015; Accepted November 18, 2015; Published November 25, 2015

Citation: Campos LMG, Pinato L, Spilla CSG, Decanini AL, Vieira IZ (2015) Neuroanatomical Mapping of s100 Immunoreactivity Reviewed. J Neuro Neurophysiol 6: 326. doi:10.4172/2155-9562.1000326

Copyright: (c) 2015 Campos LMG, et al.This is an open-access article distributed under the terms of the Creative Commons Attribution License, which permits unrestricted use, distribution, and reproduction in any medium, provided the original author and source are credited. 
a

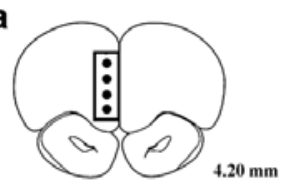

b
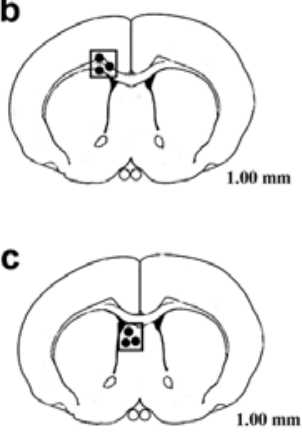

d

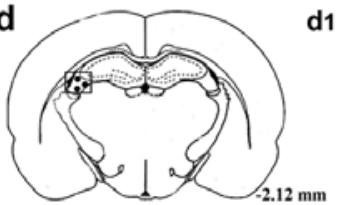

a1

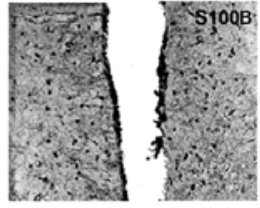

b1

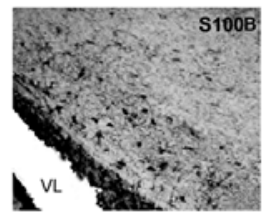

cortex

corpus callosum

c1

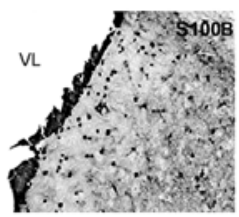

septal part

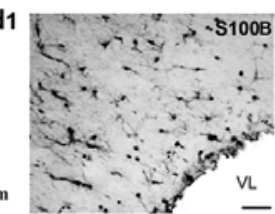

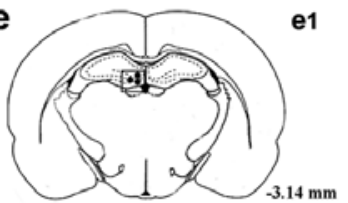

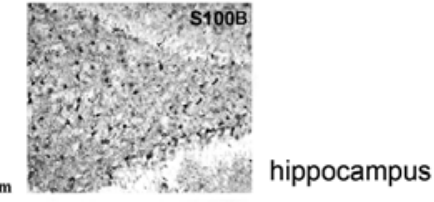

f
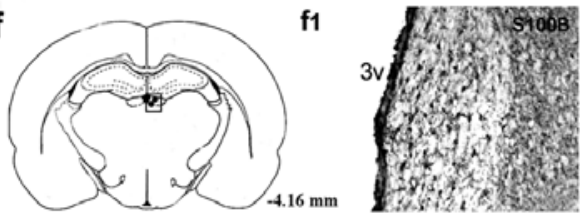

habenular comm

g

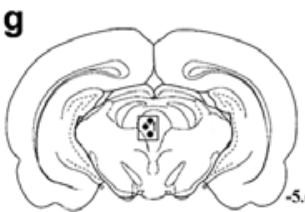

g1

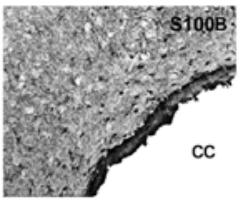

lateral

periaquedutal gray

h

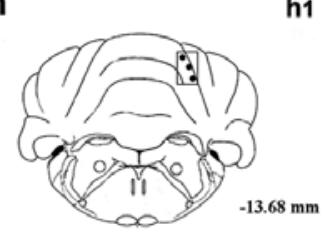

h1

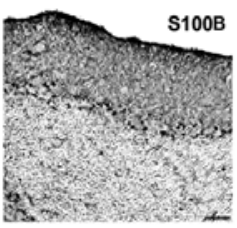

cerebellum

Figure 2 Bright-field photomicrographs showing expression of the S100B protein (indirect immunohistochemistry) along the rostrocaudal axis of the adult male rat brain. S100B-IR in different brain areas revealed a heterogeneous pattern of cell population with the strongest density in the periventricular areas: (b1): the corpus callosum, (c1): lateral part of the septal area, (d1): the fimbria of the hippocampus, (f1): the habenular comn, (g1): lateral periaquedutal gray. The cortical area adjacent to longitudinal fissure (a1), the central region of hippocampus between dentate gyrus (e1) and specific cerebellar layers (h1) also showed a high density of cells that were S100B-IR. Schematic drawings in a, b, c, d, e, f, g and h were obtained from Paxinos and Watson, 1998. The squares indicate the respective magnified areas. Scale bar: $100 \mu \mathrm{m}$.

The expression pattern of S100B could be representative of its function in the maintenance of $\mathrm{Ca} 2+$ homeostasis, energy metabolism, cellular structure, regulation of intracellular signal transduction, cell cycle, as well as synaptic plasticity as observed in memory and learning studies $[1,2,14,15,16]$.

As a matter of fact there is a $\mathrm{S} 100 \mathrm{~B}$ expression in the hippocampus under basal conditions (Figure 2, Table 1) and also an evidence of daily and developmental homestatic variations in the hippocampus of male and female rats [17]. This region was characterized by a dense distribution of S100B-IR cells throughout the rostrocaudal axis (Figure $2 \mathrm{~d} 1, \mathrm{e} 1$ ) that were colocalized with GFAP-IR, mainly in the hippocampus'fimbria (Figure 3C2, Table. 2). These findings are consistent with suggestions that S100B could be important to hippocampal neuroplasticity [18-23].

It must be pointed that beside S100B present a high colocalization with GFAP in the periventricular area, hippocampal formation and in the septal area there are some S100B-IR cells that do not express GFAP mainly in the cortex (Figure 3 A2, B2; Figure 4, Table 2). These cells had an irregular shape, and the whole cell body was stained, although the immunoreactivity is stronger in the cytoplasm than in processes (Figure $5 \mathrm{cl}$ and $\mathrm{c2}$ ).

In the telencephalon, a greater amount of S100B immunolabeling was observed in the frontal cortex compared to the other lobes (Figure 2 al, Table 1) in physiological [11,24] and pathological [25] conditions. Oval-shaped cells with few ramifications were labeled specifically in the region of the medial orbital cortex and area 1 and 2 of the cingulate

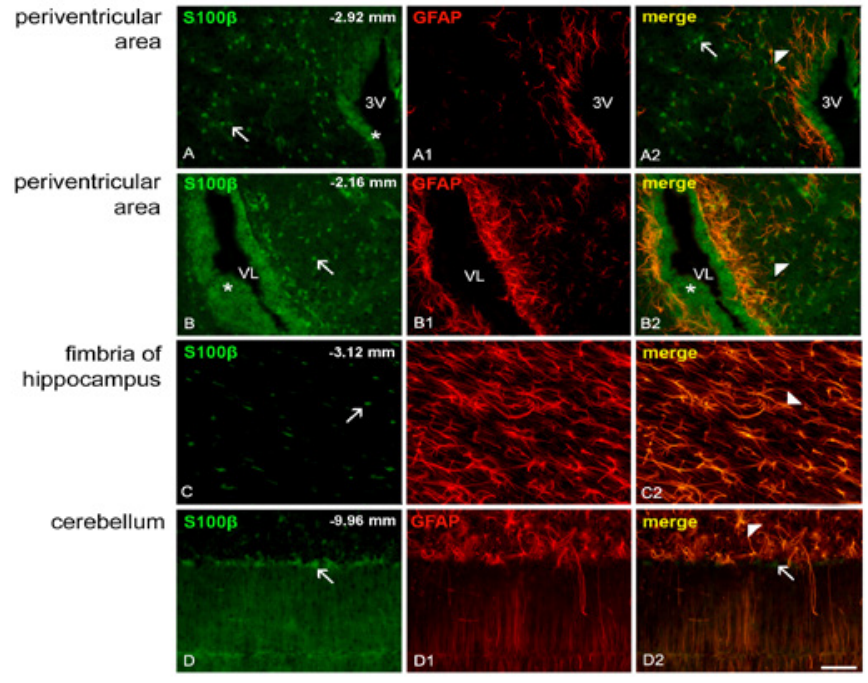

Figure 3: Photomicrographs of brain coronal sections of the Wistar rat double labeled by immunofluorescence (GFAP/red and S100B/green) Arrowheads indicate the high S100B and GFAP colocalization observed in the periventricular areas (yellow in A2 and B2), in the fimbria of the hippocampus (yellow in C2) and in the cerebellum (yellow in D2). Arrow indicates S100B-IR cells. Note that many S100B-IR cells (green) are not also GFAP IR (red) in A2 and D2. Asterisks indicate S100B-IR ependymal cells. Scale bar: $100 \mu \mathrm{m}$. 
Citation: Campos LMG, Pinato L, Spilla CSG, Decanini AL, Vieira IZ (2015) Neuroanatomical Mapping of s100 Immunoreactivity Reviewed. J Neurol Neurophysiol 6: 326. doi:10.4172/2155-9562.1000326

Page 3 of 8

\begin{tabular}{|c|c|c|c|c|c|c|c|c|}
\hline \multicolumn{9}{|c|}{ Mapping and identity of cells expressing S100B protein in the brain under physiological and pathological conditions. } \\
\hline & \multicolumn{5}{|c|}{ Physiological Conditions } & \multicolumn{3}{|c|}{ Pathological Conditions } \\
\hline & $\begin{array}{l}\text { Data from } \\
\text { our study }\end{array}$ & $\begin{array}{c}\text { Steiner et al., } \\
2007\end{array}$ & Müller, 1992 & $\begin{array}{c}\text { Dyck et al., } \\
1993\end{array}$ & $\begin{array}{l}\text { Boyes et } \\
\text { al.,1986 }\end{array}$ & $\begin{array}{c}\text { Sathe et al., } \\
2012\end{array}$ & $\begin{array}{c}\text { Steiner et al., } \\
2008\end{array}$ & $\begin{array}{c}\text { Van Eldik and } \\
\text { Griffin, } 1994\end{array}$ \\
\hline TELENCEPHALON & & & & & & $\varnothing$ & & \\
\hline Frontal Cortex & $\square$ & $\square \bullet$ & & & • & & $\square$ & $\square \bullet$ \\
\hline medial orbital córtex & $\square$ & & & & & & $\square$ & \\
\hline cingulate cortex, area 1 & $\varnothing$ & & & & & & $\square$ & \\
\hline visual cortex & $\varnothing$ & & $\Delta \square \bullet$ & $\Delta \square \bullet$ & & & & \\
\hline Corpus callosum & $\Delta \square$ & $\square \bullet$ & & & $\bullet$ & & & \\
\hline Septal region & & $\varnothing$ & $\varnothing$ & $\varnothing$ & $\varnothing$ & $\varnothing$ & $\varnothing$ & $\varnothing$ \\
\hline lateral ventricles cell ependymal & $\Delta \square \bullet$ & & & & & & & \\
\hline lateral septal nu, dorsal part & $\Delta \square \bullet$ & & & & & & & \\
\hline lateral septal nu, dorsal part intermédia & $\Delta \square \bullet$ & & & & & & & \\
\hline lateral septal nu, dorsal part ventral & $\Delta \square \bullet$ & & & & & & & \\
\hline Hippocampal region & & $\varnothing$ & $\varnothing$ & $\varnothing$ & - & $\varnothing$ & $\square$ & $\square \bullet$ \\
\hline dentate gyrus (CA4) & $\Delta \square \bullet$ & & & & & & & \\
\hline hippocampus (CA1, CA2, CA3) & $\Delta \square \bullet$ & & & & & & & \\
\hline Fimbria & $\Delta \square \bullet$ & & & & & & & \\
\hline Basal nuclei region & & $\varnothing$ & $\varnothing$ & $\varnothing$ & $\bullet$ & $\varnothing$ & $\varnothing$ & $\varnothing$ \\
\hline caudate nuclei & $\Delta \square$ & & & & & & & \\
\hline DIENCEPHALON & & $\varnothing$ & $\varnothing$ & $\varnothing$ & $\varnothing$ & $\varnothing$ & $\varnothing$ & $\varnothing$ \\
\hline Thalamus region & & & $\varnothing$ & $\varnothing$ & $\varnothing$ & $\varnothing$ & $\varnothing$ & \\
\hline paraventricular th nu, posterior & $\square \bullet$ & & & & & & & \\
\hline Hipothalamus region & & $\varnothing$ & $\varnothing$ & $\varnothing$ & $\varnothing$ & $\varnothing$ & $\varnothing$ & $\varnothing$ \\
\hline periventricular hypothamic nu & $\Delta \square \bullet$ & & & & & & & \\
\hline 3rd ventricle region & $\Delta \square \bullet$ & & & & & & & \\
\hline ependymal cell & $\square$ & & & & & & & \\
\hline BRAINSTEM & & $\varnothing$ & $\varnothing$ & $\varnothing$ & $\square$ & $\varnothing$ & $\varnothing$ & $\square \bullet$ \\
\hline Substantia nigra & $\square$ & & & & $\square$ & $\square \bullet$ & & \\
\hline Pyramide & $\Delta \square \bullet$ & & & & & $\varnothing$ & & \\
\hline Raphe nuclei region & & $\varnothing$ & $\varnothing$ & $\varnothing$ & $\varnothing$ & $\varnothing$ & $\varnothing$ & $\varnothing$ \\
\hline pallidus raphe nu & $\Delta \square \bullet$ & & & & & & & \\
\hline ventricle perinvetricular region & $\Delta \square \bullet$ & & & & & & & \\
\hline CEREBELLUM & & $\varnothing$ & $\varnothing$ & $\varnothing$ & & $\varnothing$ & $\varnothing$ & $\square \bullet$ \\
\hline \multicolumn{9}{|l|}{ Cerebellar Cortex region } \\
\hline Bergman cell & $\square$ & & & & $\square$ & & & \\
\hline granulosa layer & $\Delta \square \bullet$ & & & & & & & \\
\hline
\end{tabular}

Table 1: S100B cell IR: S100B IR (口); GFAP IR $(\Delta)$; Colocalization of S100B/GFAP IR(•); $(\varnothing)$ not analyzed.

cortex. This labeling was found predominantly in the rostral portions and was markedly decreased moving in the caudal direction. The exception was the visual cortex that showed high expression of S100B [26,27]. In physiological condition $[11,24]$ it was also shown that S100B at low doses stimulates astrocyte cell line proliferation [19]. On the other hand, in pathological conditions [25] S100B at higher concentrations stimulates nitric oxide synthase (iNOS) activity and increase the mRNA levels of this enzyme in rat cortical astrocytes via activation of NF- $\kappa B$ [28].
In the corpus callosum (medial surface of the telencephalon): higher S100B-IR was observed in the genu (anterior portion) (Figure $5 \mathrm{C} \mathrm{c2}$; Figure. $2 \mathrm{~b} 1$, Table 1), when compared to the splenium (posterior portion). The S100B-IR cells, similar to those of the cortex, showed an oval shape with few branches (Figure 5C c2).

In the septal region (medial surface of the telencephalon): S100BIR cells were detected in the dorsal, medial and ventral septal nuclei 
Citation: Campos LMG, Pinato L, Spilla CSG, Decanini AL, Vieira IZ (2015) Neuroanatomical Mapping of s100 Immunoreactivity Reviewed. J Neurol Neurophysiol 6: 326. doi:10.4172/2155-9562.1000326

Page 4 of 8

Mapping of cells expressing S100B protein in the brain under physiological conditions.

\begin{tabular}{|c|c|c|c|c|c|}
\hline & Data from our study & Gos et al., 2013 & Steiner et al., 2007 & $\begin{array}{l}\text { Dyck et al., 1993; } \\
\text { Müller, } 1992\end{array}$ & Boyes et al.,1986 \\
\hline TELENCEPHALON & + & + & + & + & + \\
\hline Frontal cortex & + & $\varnothing$ & + & $\varnothing$ & + \\
\hline Medial orbital cortex & + & $\varnothing$ & + & $\varnothing$ & $\varnothing$ \\
\hline Cingulate cortex, area 1 & + & $\varnothing$ & $\varnothing$ & $\varnothing$ & $\varnothing$ \\
\hline Cingulate cortex, area 2 & + & $\varnothing$ & $\varnothing$ & $\varnothing$ & $\varnothing$ \\
\hline Prelimbic cortex & + & $\varnothing$ & $\varnothing$ & $\varnothing$ & $\varnothing$ \\
\hline Infralimbic cortex & + & $\varnothing$ & $\varnothing$ & $\varnothing$ & $\varnothing$ \\
\hline Secundary motor cortex & + & $\varnothing$ & $\varnothing$ & $\varnothing$ & $\varnothing$ \\
\hline primary motor cortex & + & $\varnothing$ & $\varnothing$ & $\varnothing$ & $\varnothing$ \\
\hline Visual cortex & $\varnothing$ & $\varnothing$ & $\varnothing$ & + & $\varnothing$ \\
\hline Corpus callosum & + & $\varnothing$ & + & $\varnothing$ & + \\
\hline Anterior comm. & - & $\varnothing$ & $\varnothing$ & $\varnothing$ & $\varnothing$ \\
\hline Septal area & + & $\varnothing$ & $\varnothing$ & $\varnothing$ & $\varnothing$ \\
\hline Lateral septal nu, dorsal part & + & & & & \\
\hline Lateral septal nu, dorsal part intermedia & + & & & & \\
\hline Lateral septal nu, dorsal part ventral & + & & & & \\
\hline Fornix & - & $\varnothing$ & $\varnothing$ & $\varnothing$ & $\varnothing$ \\
\hline Hippocampus & + & + & + & $\varnothing$ & + \\
\hline dentate gyrus (CA4) & + & + & $\varnothing$ & & \\
\hline hippocampus (CA1, CA2, CA3) & + & + & + & & \\
\hline Subiculum & + & + & $\varnothing$ & & \\
\hline Fimbria of hippocampus & + & + & $\varnothing$ & & \\
\hline Basal Nuclei & + & $\varnothing$ & $\varnothing$ & $\varnothing$ & + \\
\hline Caudate & + & & & & \\
\hline Putamen & + & & & & \\
\hline Globus pallidus & + & & & & \\
\hline Claustrum & + & & & & \\
\hline Amygdala & & $\varnothing$ & $\varnothing$ & $\varnothing$ & $\varnothing$ \\
\hline lateral amyd nu, dorsolateral & - & & & & \\
\hline lateral amyd nu, ventromedial & + & & & & \\
\hline Posteromed cortical amyg nu & + & & & & \\
\hline DIENCEPHALON & & $\varnothing$ & $\varnothing$ & $\varnothing$ & $\varnothing$ \\
\hline \multicolumn{6}{|l|}{ Thalamus } \\
\hline paraventricular thalamic nu & + & & & & \\
\hline paraventricular th nu, posterior & + & & & & \\
\hline Stria medullaris of thalamus & - & & & & \\
\hline Epithalamus & + & $\varnothing$ & $\varnothing$ & $\varnothing$ & $\varnothing$ \\
\hline lateral habenular nu & + & & & & \\
\hline medial habenular nu & + & & & & \\
\hline habenular comm & + & & & & \\
\hline Subthalamus & - & $\varnothing$ & $\varnothing$ & $\varnothing$ & $\varnothing$ \\
\hline Zona incerta & - & & & & \\
\hline Hypothalamus & & $\varnothing$ & $\varnothing$ & $\varnothing$ & $\varnothing$ \\
\hline Medial preoptic área & - & & & & \\
\hline supraoptic nu & - & & & & \\
\hline periventricular hypothamic nu & + & & & & \\
\hline Subparaventricular zone of hi & - & & & & \\
\hline Anterior hypoth area posterior & - & & & & \\
\hline ventromedial hy nu, ant & - & & & & \\
\hline ventromed nu, dorsomed & - & & & & \\
\hline ventromed hypoth nu, cent & - & & & & \\
\hline ventromed nu, ventrolat & - & & & & \\
\hline premammillary nu, dorsal & - & & & & \\
\hline medial mammillary nu, medial & - & & & & \\
\hline
\end{tabular}


Citation: Campos LMG, Pinato L, Spilla CSG, Decanini AL, Vieira IZ (2015) Neuroanatomical Mapping of s100 Immunoreactivity Reviewed. J Neurol Neurophysiol 6: 326. doi:10.4172/2155-9562.1000326

Page 5 of 8

\begin{tabular}{|c|c|c|c|c|c|}
\hline mammillary nu, lateral & - & & & & \\
\hline arcuate hy nu, medial post & + & & & & \\
\hline BRAINSTEM & & $\varnothing$ & $\varnothing$ & $\varnothing$ & + \\
\hline Substantia nigra & - & & & & + \\
\hline superior colliculus & - & & & & $\varnothing$ \\
\hline inferior colliculus & - & & & & $\varnothing$ \\
\hline nucleus gracile & - & & & & $\varnothing$ \\
\hline nucleus cuneiforme & - & & & & $\varnothing$ \\
\hline Pyramids & + & & & & $\varnothing$ \\
\hline facial nerve, nu & - & & & & $\varnothing$ \\
\hline hypoglossal nerve, nu & - & & & & $\varnothing$ \\
\hline reticular nu, lateral & - & & & & $\varnothing$ \\
\hline vestibular nu, medial & - & & & & $\varnothing$ \\
\hline vestibular nu, inferior & - & & & & $\varnothing$ \\
\hline nucleo tractus solitarius & - & & & & $\varnothing$ \\
\hline area postrema & - & & & & $\varnothing$ \\
\hline lateral periaquedutal gray & + & & & & $\varnothing$ \\
\hline lateral periaquedutal, central & + & & & & $\varnothing$ \\
\hline ependymal cell & + & & + & & $\varnothing$ \\
\hline locus coeruleus & - & & & & $\varnothing$ \\
\hline tegmental nu, dorsal & - & & & & $\varnothing$ \\
\hline tegmental nu, ventral & - & & & & $\varnothing$ \\
\hline RAPHE & + & $\varnothing$ & $\varnothing$ & $\varnothing$ & $\varnothing$ \\
\hline dorsal raphe nu & - & & & & \\
\hline caudal linear raphe nu & - & & & & \\
\hline median and paramedian raphe nu & - & & & & \\
\hline magnus raphe nu & - & & & & \\
\hline raphe obscurus nu & - & & & & \\
\hline pallidus raphe nu & + & & & & \\
\hline pontine raphe nu & - & & & & \\
\hline CORTEX CEREBELLUM & + & $\varnothing$ & $\varnothing$ & $\varnothing$ & + \\
\hline Granulosa layer & + & & & & $\varnothing$ \\
\hline Molecular layer & - & & & & $\varnothing$ \\
\hline Bergman cell & + & & & & + \\
\hline
\end{tabular}

Table 2: S100B cell IR: Present (+), Absent (-), Not analyzed $(\varnothing)$

throughout the rostrocaudal axis (Figure $2 \mathrm{c1}$ ), mainly in the dorsal portion and periventricular regions.

In the basal nuclei: weak S100B-IR was observed in the claustrum mainly close to the insular cortex and in the corpus striatum. Similarly, weak S100B-IR as observed in putamen, head of the caudate nucleus, in the caudal portions of the globus pallidus and throughout the areas adjacent to the lateral ventricles.

In the amygdaloid complex: weak S100B-IR was observed throughout the medial ventroposterior amygdaloid nucleus and in the rostral portion of the medial posterior cortical nucleus.

In the Diencephalon, the paraventricular nucleus of the thalamus presents S100B-IR throughout its anteroposterior axis, with GFAP-IR colocalization mainly in the periventricular portion. S100B-IR cells were also detected in the medial portion of habenula throughout the rostrocaudal axis, in the lateral habenular nucleus as well as in the caudal portion of the habenular commissure in the epithalamus (Figure $2 \mathrm{f1}$ ). In the region of the hypothalamus $\mathrm{S} 100 \mathrm{~B}$ was colocalized with GFAP along the third ventricle in periventricular areas including the periventricular nucleus (Figure 3A2). Colocalization of S100B with ependymal cells was also observed in this region (Figure $3 \mathrm{~B} 2$ asterisk).
In the Brainstem, S100B-IR cells were detected in ependymal cells in the caudal portion of the fourth ventricle (Figure 3 B2 - asterisk) and colocalized with GFAP-IR in periventricular cells (Figure 3 A2, B2; Figure $4 \mathrm{~b}$ ). In pyramids and in the nucleus raphe pallidus S100B-IR cells were observed along the rostrocaudal axis. The nucleus tractus solitarius also had S100B-IR cells in the rostral portion of the gracile tubercles.

In the Cerebellum, S100B-IR cells were observed mainly in Bergman cells around Purkinje neurons (Figure 5 a1, a2) which are consistent with previous results that showed S100B-IR in this specialized type of astrocyte [29]. Additionally, there was colocalization of S100B with GFAP in the granular layer (Figure 3 D2).

\section{S100B in Pathological Conditions}

In pathological conditions, secretion of S100B from astrocytes is stimulated by metabolic stress (oxygen, serum and glucose deprivation) and is suppressed by glutamate [30,31]. Once released, S100B can affect neurons, primarily by engagement of RAGE (Receptor for Advanced Glycation End Products), its primary receptor [32]. Then, depending on the intracellular calcium concentration, it exerts either a trophic (nanomolar) or destructive (micromolar levels) effect on neurons when can lead to cellular lesions or death $[18,19,33,34]$. 


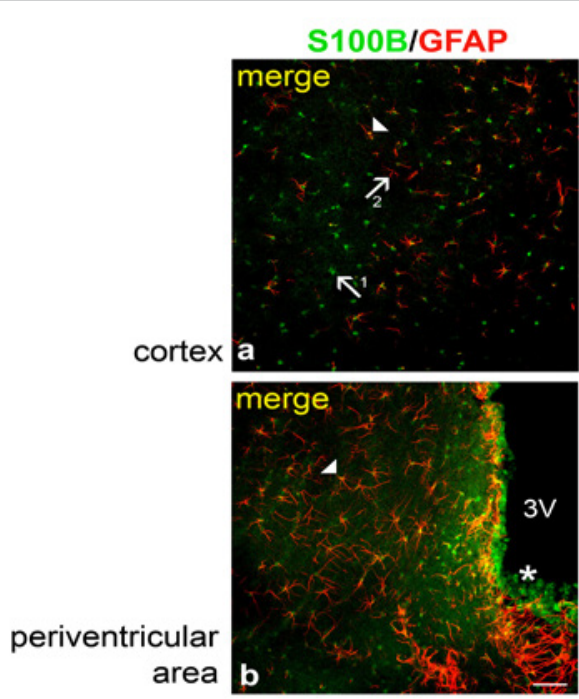

Figure 4: S100B IR and GFAP-IR in the cortex and periventricular areas of Wistar rats. Arrow 1 indicates S100B-IR cells (green), Arrow 2 indicates GFAP-IR cells (red) $\mathbf{a}$, and the arrowheads indicate double-immunoreactive cells (yellow) observed in the cortex (a) and periventricular areas (b). Note that in contrast to the periventricular areas, the colocalization of S100B-IR in GFAP-IR cells was lower in cortical areas (a). In b asterisk indicates S100B-IR ependymal cells. Scale bar: $100 \mu \mathrm{m}$. a

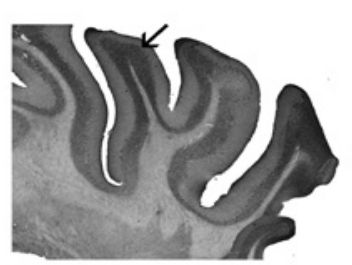

b
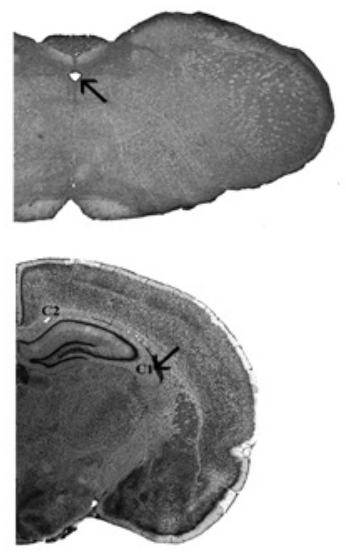

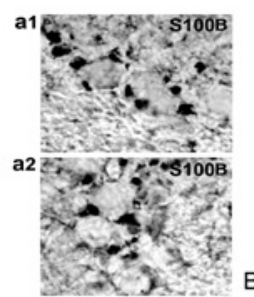

Bergman Cell
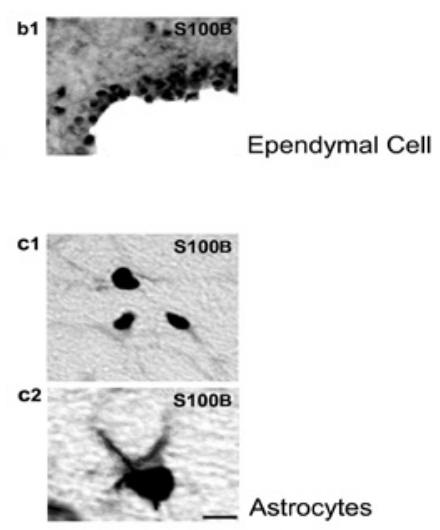

Figure 5: Double labeling of $\mathrm{S} 100 \mathrm{~B}$ and $\mathrm{NeuN}$ (by indirect immunofluorescence) in the cortex of Wistar rats. Arrowhead indicates NeuN-IR cell (green) and arrow indicates S100B-IR cell (red). Note that neurons (green NeuN-IR) are also not labeled with S100B-IR (red). This finding was true for the whole rostro-caudal axis. Scale bar: $100 \mu \mathrm{m}$.

Variations in the S100B levels have rendered it a status as biomarker for astrocytic damage or dysfunction. Several postmortem studies on Alzheimer's disease and Down's syndrome describe predominant S100B immunostaining in reactive astrocytes surrounding neuritic plaques $[35,36]$.

\section{A role in heterogeneously distribution of S100B Protein}

In this review we observed that $\mathrm{S} 100 \mathrm{~B}-\mathrm{IR}$ in physiological condition is heterogeneously distributed in the brain and in diferent cell types with more pronounced expression in areas such as the cerebral cortex and cerebellum, hippocampus and periventricular areas. Its physiologic role in these areas should be examined in future.

The expression of S100B protein is known to be colocalized with GFAP, which is highly expressed in astrocytes [37]. This review showed that the astrocytes GFAP-IR of periventricular areas exhibit a large amount of co-localization with S100B-IR. In these situations, S100BIR is primarily located in the astrocytes cytoplasm, while GFAP-IR is expressed primarily in astrocytes extentions $[38,39]$. This distribution could indicate a homeostatic role of S100B in glial cells that involves ventricular areas. Similarly co-localization of S100B with ependymal cells, suggests that in the CNS, cells other than astrocytes can secrete this protein into the CSF. In chronic neuropathologies (e.g., in Parkinson's disease), S100B protein levels in the CSF are increased. This high expression of S100B in periventricular areas probably reflects the role of these areas in detecting the health condition and in turn reflexly regulating S100B levels in the CSF [40].

In contrast to the periventricular areas, GFAP-IR and S100B-IR colocalization in astrocytes was lower in cortical areas maybe because of its state of activation since GFAP is a marker for activated astrocytes $[41,42]$. Thus, one possible hypothesis is that under normal conditions, astrocytes in the periventricular areas remain more active than in the cerebral cortex.

Astrocytes are the most common glial cells in the CNS, and they feature a heterogeneous group that has distinct functions such as the regulation of metabolism and control of glucose by modulating neuronal release of neuroactive substances and the control of neurotransmitter in the synaptic cleft $[38,43$,$] .$

\section{Conclusion}

S100B exerts intracellular and extracellular actions that are not completely clarified. Despite it is possible to detect it either in brain tissue or in bodily fluids, most studies of S100B have been performed in bodily fluids of humans in pathological conditions or in animal pathological models. Increased levels of S100B in fluids have been positively correlated with brain pathological conditions like cerebral infarction, meningitis, multiple sclerosis and dementia.

Identity of cells expressing this protein in the brain under physiological conditions and in pathological conditions showed that this protein is presented in astrocytes, oligodendrocytes, Bergman and ependymal cells in both conditions. In physiological conditions there is a high but not total co-localization of S100B and GFAP in the periventricular areas, hippocampus and in the septal area. On the other hand, cortical regions are highlighted predominantly by S100B-IR astrocytes that not express GFAP.

Regarding the brain mapping in physiological conditions, the more pronounced S100B expression was in areas such as the cortex cerebral and cerebellum, hippocampus and periventricular areas. All main areas of telencephalon, corpus callosum, Septal area, Hippocampus, Basal Nuclei, almost all parts of Amygdala and Thalamus, Epithalamus, periventricular hypothamic nucleus, periaquedutal gray, Substantia nigra and cerebellum Granulosa layer express S100B-IR.

Anterior commissure, Subthalamus, Zona incerta, almost all Hypothalamic nuclei, almost all brainstem nuclei, cerebellum 
Citation: Campos LMG, Pinato L, Spilla CSG, Decanini AL, Vieira IZ (2015) Neuroanatomical Mapping of s100 Immunoreactivity Reviewed. J Neurol Neurophysiol 6: 326. doi:10.4172/2155-9562.1000326

molecular layer do not express S100B-IR in physiological conditions. The Substantia nigra was the only area analyzed until this moment that shows co-localization of S100B-IR and GFAP-IR in pathological conditions unlike in the physiological conditions.

The high expression of S100B in periventricular areas could be due to these areas sensing the state of health and regulating S100B levels in the CSF.

This complete description can be potentially used for researches that aim to consider changes in S100B expression in different pathologies.

\section{Acknowledgments}

This work was supported by Fundação de Amparo a Pesquisa de São Paulo (FAPESP), and LMGC is graduate fellow of Coordenação de Aperfeiçoamento de Pessoal de Nivel Superior (CAPES).

\section{References}

1. Donato $R$ (2003) Intracellular and extracellular roles of $S 100$ proteins. Microsc Res Tech 60: 540-551.

2. Donato R, Sorci G, Riuzzi F, Arcuri C, Bianchi R, et al. (2009) S100B's double life: intracellular regulator and extracellular signal. Biochim Biophys Acta 1793: 1008-1022.

3. Gonçalves CA, Leite MC, Nardin P (2008) Biological and methodological features of the measurement of $\mathrm{S} 100 \mathrm{~B}$, a putative marker of brain injury. Clin Biochem 41: 755-763.

4. Al-Ayadhi LY, Mostafa GA (2012) A lack of association between elevated serum levels of S100B protein and autoimmunity in autistic children. J Neuroinflammation 9: 54

5. Kleindienst A, Ross Bullock M (2006) A critical analysis of the role of the neurotrophic protein S100B in acute brain injury. J Neurotrauma 23: 1185-1200.

6. Infante JR, Martínez A, Ochoa J, Cañadillas F, Torres-Avisbal M, et al. (2003) Cerebrospinal fluid S-100 protein levels in neurological pathologies. J Physiol Biochem 59: 255-261.

7. Portela LV, Brenol JC, Walz R, Bianchin M, Tort AB, et al. (2002) Serum S100B levels in patients with lupus erythematosus: preliminary observation. Clin Diagn Lab Immunol 9: 164-166.

8. Storoni M, Verbeek MM, Illes Z, Marignier R, Teunissen CE, et al. (2012) Serum GFAP levels in optic neuropathies. J Neurol Sci 317: 117-122.

9. Steinacker P, Weidehaas K, Cepek L, Feneberg E, Kretzschmar HA, et al. (2013) Influence of the blood-CSF-barrier function on S100B in neurodegenerative diseases. Acta Neurol Scand 128: 249-256.

10. Nguyen DN, Huyghens L, Zhang H, Schiettecatte J, Smitz J, et al. (2014) Cortisol is an associated-risk factor of brain dysfunction in patients with severe sepsis and septic shock. Biomed Res Int 2014: 712742.

11. Steiner J, Bernstein HG, Bielau H, Berndt A, Brisch R, et al. (2007) Evidence for a wide extra-astrocytic distribution of S100B in human brain. BMC Neurosci 8: 2.

12. Gazzolo D, Lituania M, Bruschettini M, Bruschettini P, Michetti F (2003) S100B protein concentrations in amniotic fluid are higher in monoamniotic than in diamniotic twins and singleton pregnancies. Clin Chem 49: 997-999.

13. Kubista H, Donato R, Hermann A (1999) S100 calcium binding protein affects neuronal electrical discharge activity by modulation of potassium currents. Neuroscience 90: 493-508.

14. Xiong Z, O'Hanlon D, Becker LE, Roder J, MacDonald JF, et al. (2000) Enhanced calcium transients in glial cells in neonatal cerebellar cultures derived from S100B null mice. Exp Cell Res 257: 281-289.

15. Nishiyama H, Knopfel T, Endo S, Itohara S (2002) Glial protein S100B modulates long-term neuronal synaptic plasticity. Proc Natl Acad Sci U S A 99: 4037-4042.

16. Rothermundt M, Peters M, Prehn JH, Arolt V (2003) S100B in brain damage and neurodegeneration. Microsc Res Tech 60: 614-632.

17. Nogueira MI, Abbas SY, Campos LG, Allemandi W, Lawson P, et al. (2009) S100beta protein expression: gender- and age-related daily changes. Neurochem Res 34: 1355-1362.
18. Whitaker-Azmitia PM, Murphy R, Azmitia EC (1990) Stimulation of astroglia $5-\mathrm{HT} 1 \mathrm{a}$ receptors releases the serotonergic growth factor, protein $\mathrm{S} 100 \mathrm{~b}$, and alters astroglial morphology. Brain Res 528: 155-158.

19. Selinfreund RH, Barger SW, Pledger WJ, Van Eldik LJ (1991) Neurotrophic protein S100 beta stimulates glial cell proliferation. Proc Natl Acad Sci U S A 88: 3554-3558.

20. Schroeter ML, Abdul-Khaliq H, Diefenbacher A, Blasig IE (2002) S100B is increased in mood disorders and may be reduced by antidepressive treatment. Neuroreport 13: 1675-1678.

21. Gage FH (2002) Neurogenesis in the adult brain. J Neurosci 22: 612-613.

22. Gage FH (2004) Structural plasticity of the adult brain. Dialogues Clin Neurosci 6: 135-141.

23. Boyes BE, Kim SU, Lee V, Sung SC (1986) Immunohistochemical co-localization of $\mathrm{S}-100 \mathrm{~b}$ and the glial fibrillary acidic protein in rat brain. Neuroscience 17: 857-865.

24. Van Eldik LJ, Griffin WS (1994) S100 beta expression in Alzheimer's disease: relation to neuropathology in brain regions. Biochim Biophys Acta 1223: 398 403.

25. Müller CM (1992) Astrocytes in cat visual cortex studied by GFAP and S-100 immunocytochemistry during postnatal development. J Comp Neurol 317: 309323.

26. Dyck RH, Van Eldik LJ, Cynader MS (1993) Immunohistochemical localization of the S-100 beta protein in postnatal cat visual cortex: spatial and temporal patterns of expression in cortical and subcortical glia. Brain Res Dev Brain Res 72: 181-192.

27. Lam AG, Koppal T, Akama KT, Guo L, Craft JM, et al. (2001) Mechanism of glial activation by $\mathrm{S} 100 \mathrm{~B}$ : involvement of the transcription factor NFkappaB. Neurobiol Aging 22: 765-772.

28. Hachem S, Laurenson AS, Hugnot JP, Legraverend C (2007) Expression of S100B during embryonic development of the mouse cerebellum. BMC Dev Bio 7: 17 .

29. Gerlach R, Demel G, König HG, Gross U, Prehn JH, et al. (2006) Active secretion of $\mathrm{S} 100 \mathrm{~B}$ from astrocytes during metabolic stress. Neuroscience 141: 1697-1701.

30. Tramontina F, Leite MC, Gonçalves D, Tramontina AC, Souza DF, et al. (2006) High glutamate decreases $\mathrm{S} 100 \mathrm{~B}$ secretion by a mechanism dependent on the glutamate transporter. Neurochem Res 31: 815-820.

31. Donato R (2007) RAGE: a single receptor for several ligands and different cellular responses: the case of certain $\mathrm{S} 100$ proteins. Curr Mol Med 7: 711-724.

32. Eriksen JL, Gillespie R, Druse MJ (2002) Effects of ethanol and 5-HT1A agonists on astroglial S100B. Brain Res Dev Brain Res 139: 97-105.

33. Fanò G, Mariggiò MA, Angelella P, Nicoletti I, Antonica A, et al. (1993) The S-100 protein causes an increase of intracellular calcium and death of PC12 cells. Neuroscience 53: 919-925.

34. Sheng JG, Mrak RE, Griffin WS (1994) S100 beta protein expression in Alzheimer disease: potential role in the pathogenesis of neuritic plaques. $J$ Neurosci Res 39: 398-404.

35. Mrak RE, Griffinbc WS (2001) The role of activated astrocytes and of the neurotrophic cytokine S100B in the pathogenesis of Alzheimer's disease. Neurobiol Aging 22: 915-922.

36. Tateishi N, Shimoda T, Yada N, Shinagawa R, Kagamiishi Y (2006) [S100B astrocyte specific protein]. Nihon Shinkei Seishin Yakurigaku Zasshi 26: 11-16.

37. Kimelberg HK, Norenberg MD (1989) Astrocytes. Sci Am 260: 66-72, 74, 76.

38. Wang DD, Bordey A (2008) The astrocyte odyssey. Prog Neurobiol 86: 342367.

39. Sathe K, Maetzler W, Lang JD, Mounsey RB, Fleckenstein C, et al. (2012) $\mathrm{S} 100 \mathrm{~B}$ is increased in Parkinson's disease and ablation protects against MPTPinduced toxicity through the RAGE and TNF-Î̀ pathway. Brain 135: 3336-3347.

40. Jabs R, Bekar LK, Walz W (1999) Reactive astrogliosis in the injured and postischemic brain. In: Walz W (Ed) Cerebral ischemia: molecular and cellular pathophysiology. Humana Press, Totowa, New Jersey 233-249.

41. Villarreal A, Seoane R, González Torres A, Rosciszewski G, Angelo MF, et al. (2014) S100B protein activates a RAGE-dependent autocrine loop in 
Citation: Campos LMG, Pinato L, Spilla CSG, Decanini AL, Vieira IZ (2015) Neuroanatomical Mapping of s100 Immunoreactivity Reviewed. J Neurol Neurophysiol 6: 326. doi:10.4172/2155-9562.1000326

Page 8 of 8

astrocytes: implications for its role in the propagation of reactive gliosis. J Neurochem 131: 190-205.

42. Farfara D, Lifshitz V, Frenkel D (2008) Neuroprotective and neurotoxic properties of glial cells in the pathogenesis of Alzheimer's disease. $\mathrm{J}$ Cell Mol Med 12: 762-780.

43. Paxinos G, Watson C (1998) The rat brain in stereotaxic coordinates, 4th edn. Academic Press, San Diego, CA. 